\title{
PENGARUH BRAND IMAGE, KUALITAS PRODUK, HARGA DAN KUALITAS LAYANAN TERHADAP KEPUTUSAN PEMBELIAN SEMEN DI PT SEMEN INDONESIA LOGISTIK CABANG GULOMANTUNG GRESIK
}

\author{
Annisatun Nur Fitriani \\ Progran Studi Kewirausahaan, Fakultas Ekonomi dan Bisnis, Universitas Muhammadiyah Gresik \\ annisatunnurfitriani@gmail.com
}

\begin{abstract}
This study aims to analyze the influence of Brand Image variables, Product Quality, Price and Service Quality on Purchasing Decisions at PT. Semen Indonesia Logistics Branch of Gulomantung Gresik. This type of research uses quantitative with a sample of 154 consumers. The sampling technique used Incidetal Sampling. The results of the study proved to show that the Brand Image variable, Product Quality, Price had a positive and significant effect and the service quality variable had a negative and significant effect on the Purchase Decision.
\end{abstract}

Keywords: Purchase Decisions, Brand Image, Product Quality, Price, Service Quality

\section{PENDAHULUAN}

Pemasaran merupakan salah satu dari kegiatan-kegiatan pokok yang dilakukan oleh para perusahaan dalam usahanya untuk mempertahankan, untuk berkembang dan untuk mendapatkan laba. Berhasil tidaknya dalam pencapaian tujuan bisnis tergantung kepada keahlian perusahaan di bidang pemasaran, produksi, keuangan maupun bidang lain. Selain itu tergantung pula pada kemampuan perusahaan untuk mengkombinasikan fungsi-fungsi tersebut agar usaha perusahaan dapat berjalan lancar. Menurut Kotler dan Amtrong (2008;09). Pemasaran sebagai proses sosial dan manajerial dimana pribadi atau organisasi memperoleh apa yang mereka butuhkan dan inginkan melalui penciptaan dan pertukaran nilai dengan yang lain dalam menghadapi persaingan bisnis perusahaan distributor juga harus mengkaji sikap konsumen terhadap produk yang dihasilkan perusahaan, agar produk yang ditawarkan kepada konsumen dapat memenuhi keinginan dan kebutuhan konsumen.

Keinginan dan kebutuhan konsumen akan selalu berubah-ubah sesuai dengan keadaan keuangan, perubahan selera, perubahan mode, gaya hidup, perubahan motivasi dan sebagainya. Semua itu sangat mempengaruhi konsumen dalam menentukan pilihanya terhadap suatu produk.Engel dan Winiard dalam (Fadila dan Ridho, 2013:2) mendefinisikan perilaku konsumen sebagai tindakan yang langsung terlibat dalam mendapatkan, mengkonsumsi, dan menghabiskan produk dan jasa, termasuk proses keputusan yang mendahului dan menyusuli tindakan ini. Pengertian diatas dapat disimpulkan perilaku konsumen merupakan tindakan atau interaksi antara pengaruh dan kesadaran dalam membuat keputusan dalam pembelian dan pengkonsumsian suatu produk.

Keputusan pembelian konsumen adalah proses merumuskan berbagai alternatif tindakan guna menjatuhkan pembelian pilihan pada salah satu alternatif tertentu untuk melakukan pembelian produk (Visser, Gattol, dan Van Der Helm, 2015;10). PT. Semen Indonesia Logistik ini merupakan perusahaan yang bergerak dibidang produk jasa yaitu pendistribusian dan memasarkan produk PT. Semen Indonesia guna menjual produknya. 
PT. Semen Indonesia Logistik ini dituntut untuk dapat mengoptimalkan manajemen pemasarannya. Pengelolaan manajemen pemasaran tidak lepas dari faktor keputusan pembelian yang diharapkan dapat menarik konsumen sebaik mungkin demi mencapai tujuan organisasi atau perusahaan. Menurut Kotler dan Amstrong (2012:157) bahwa keputusan pembelian mengacu pada perilaku pembelian akhir dari konsumen, baik individual, maupun rumah tangga yang membeli barang dan jasa untuk konsumsi pribadi. Berikut ini adalah laporan omset penjualan produk PT. Semen Indonesia di PT. Semen Indonesia Logistik Cabang Gulomantung Gresik.

Dapat dilihat omset yang diperoleh periode Juli sampai November tahun 2017 mengalami penurunan, pada bulan Juli memperoleh omset Rp. 2.530.888.297, bulan Agustus memperoleh Rp. 2.111.933.252, bulan September memperoleh Rp. 2.151.682.341, bulan Oktober memperoleh Rp. 2.145.204.681, bulan November memperoleh Rp. 811.982.725.

Keputusan pembelian merupakan faktor yang sangat penting bagi keberadaan dan perkembangan bisnis PT. Semen Indonesia Logistik. Saat ini banyak perusahaan yang semakin memahami arti penting dari Keputusan pembelian dan menjalankan strategi guna menjaga dan memperbanyak penjualan. Untuk memenangkan persaiangan perusahaan harus tetap menjaga dan mempertahankan para konsumennya dengan cara meningkatkan penjualan. Merek (brand) merupakan salah satu faktor penting dalam kegiatan pemasaran. Merek memberikan kontribusinya terhadap perusahaan dalam rangka memengaruhi keputusan konsumen untuk membeli atau menolak suatu barang atau jasa yang ditawarkan. Untuk membuat pilihan di antara berbagai macam alternatif merek, konsumen membutuhkan informasi. Merek akan memberikan suatu informasi yang ringkas tentang suatu produk yang diinginkan oleh konsumen. Namun merek memiliki identitas yang berbeda dengan produk atau jasa.

Dengan penjelasan singkat yang dikemukakan sebelumnya penelitian ini bertujuan untuk menjelaskan variabel brand image, kualitas produk, dan harga yang mempengaruhi keputusan pembelian. Variabel-variabel inilah yang sebaiknya dipahami oleh perusahaan yang mengarahkan pelanggan kepada keputusan pembelian. Berdasarkan uraian pada latar belakang di atas, maka peneliti melakukan penelitian dengan judul "Pengaruh Brand Image, Kualitas Produk, Harga, dan Kualitas Layanan terhadap Keputusan Pembelian Semen di PT. Semen Indonesia Logistik Cabang Gulomantung Gresik".

\section{TINJAUAN PUSTAKA}

Penelitian yang dilakukan oleh Wanda (2015) tentang Pengaruh Harga Dan Pelayanan Terhadap Keputusan Pembelian Di Mini Market Lulu Mart Samarinda. Teknik analisis dalam penelitian ini menggunakan regresi linier berganda. Hasil uji simultan (Uji F) menunjukan bahwa secara bersama-sama variabel harga dan pelayanan berpengaruh signifikan terhadap keputusan pembelian. Hasil uji parsial (Uji t) menunjukkan bahwa dari kedua variabel $\mathrm{X}$ yakni harga dan pelayanan yang paling berpengaruh signifikan terhadap keputusan pembelian adalah pelayanan.

Penelitian Amrullah, Siburian, dan Zainurossalamia ZA (2016) tentang Pengaruh Kualitas Produk Dan Kualitas Layanan Terhadap Keputusan Pembelian Sepeda Motor Honda, dengan sampel sebanyak 60 konsumen yang memenuhi kriteria dan teknik analisis yang digunakan adalah regresi linier berganda. Hasil penelitian ini menunjukkan bahwa Kualitas Produk berpengaruh positif dan signifikan terhadap Keputusan Pembelian dan Kualitas Layanan berpengaruh positif dan signifikan terhadap Keputusan Pembelian.

Penelitian Pravianda (2017) tentang Pengaruh Harga Dan Reputasi Perusahaan Terhadap Keputusan Pembelian Produk Niion Indonesia (Studi Kasus Pada Konsumen Di Kota Bandung). Alat analisis penelitian ini yang digunakan adalah regresi linier berganda. Hasil dari penelitian ini adalah adanya pengaruh yang 
signifikan antara harga dan reputasi perusahaan terhadap keputusan pembelian.

\section{Pemasaran}

Menurut Kotler dan Amstrong $(2013 ; 29)$ pemasaran merupakan proses dimana perusahaan menciptakan nilai untuk konsumen dengan cara menjalin hubungan yang baik dan kuat untuk membangun nilai dari pelanggan. Pemasaran merupakan suatu kegiatan untuk menciptakan atau menawarkan produk maupun jasa yang mempunyai nilai kepada individu dan kelompok (Kotler dan Amstrong (2013;12).

\section{Konsep Umum Pemasaran}

Tercapainya suatu tujuan perusahaan yaitu meletakkan pemasaran sebagai pusat kegiatan dan memimpin semua unit yang diproduksi ke arah tujuan perusahaan diperlukan sebuah konsep pemasaran. Konsep pemasaran merupakan cara untuk mencapai tujuan perusahaan yang dimulai dari menentukan apa yang menjadi kebutuhan dan keinginan pangsa pasar serta memberikan kualitas yang baik agar konsumen bisa merasakan kepuasan secara efektif dan efisien. Menurut Kotler (2013;22) terdapat empat konsep pemasaran yaitu pasar sasaran, kebutuhan pelanggan, pemasaran terintegrasi dan kemampuan perusahaan dalam menghasilkan laba melalui kepuasan konsumen.

\section{Manajemen Pemasaran}

Kottler dan Keller (2009;5) mengatakan bahwa manajemen pemasaran merupakan seni dan ilmu yang meliputi kegiatan memilih pangsa pasar, menumbuhkan pelanggan serta mempertahankannya dengan cara menciptakan komunikasi pelanggan yang baik. Manajemen pemasaran adalah proses yang dilakukan perusahaan untuk merencanakan atau mengkoordinasikan program-program perusahaan agar dapat mencapai tujuannya.

\section{Brand Image}

Menurut Kotler (2013;331) citra diartikan sebagai jumlah dari keyakinankeyakinan, gambaran-gambaran, kesan-kesan yang dipunyai seseorang pada suatu obyek. Obyek yang dimaksud bisa orang, organisasi, kelompok orang atau lainnya yang diketahui. Jikaobyek itu berupa organisasi, berarti keseluruhan keyakinan, gambaran dan kesan atas organisasi dari seseorang adalah citra

\section{Kualitas Produk}

Menurut Kotler dan Amstrong (2013;283) Kualitas produk adalah kemampuan suatu produk untuk melaksanakan fungsinya, meliputi daya tahan, keandalan, ketepatan, kemudahan operasi dan perbaikan, serta atribut bernilai lainnya.

\section{Harga}

Harga merupakan suatu nilai untuk mendapatkan suatu produk kepada konsumen manfaat dari memiliki atau menggunakan pada satu waktu tertentu. Agar dapat sukses dalam memasarkan suatu barang atau jasa, setiap perusahaan harus menetapkan harganya secara tepat. Harga merupakan unsur bauran pemasukan atau pendapatan bagi perusahaan. Kotler dan Keller $(2009 ; 67)$ menyatakan harga adalah salah satu elemen bauran pemasaran yang menghasilkan pendapatan.

\section{Kualitas Layanan}

Menurut Tjiptono dan Chandra (2016;115) kualitas sebagai kondisi dinamis yang berhubungan dengan produk, jasa, sumber daya manuasi proses dan lingkungan yang memenuhi atau melebihi harapan, sedangkan menurut Kotler dan Keller $(2009$;134) mengungkapkan kualitas adalah totalitas fitur dan karakteristik produk atau jasa yang bergantung pada kemampuannnya untuk memuaskan kebutuhan yang di harapkan, kualitas jasa atau kualitas layanan berkontribusi signifikan bagi penciptaan diferensiasi, position, dan strategi bersaing setiap organisasi pemasaran.

\section{Keputusan Pembelian}

Keputusan pembelian menurut Tjiptono $(2008 ; 21)$ adalah sebuah proses dimana seorang konsumen mempunyai masalah dan mengenal masalah tersebut, mencari beberapa informasi mengenai macam produk dengan berbagai merek yang kemudian mengevaluasi masing-masing alternatif tersebut manakah yang baik untuk memecahkan masalahnya, yang kemudian akan dilakukan keputusan pembelian.

Hubungan Brand Image terhadap Keputusan Pembelian 
Wicaksono $(2011 ; 153)$, mengemukakan pentingnya pengembangan Brand Image dalam keputusan pembelian. Brand image yang dikelola dengan baik akan menghasilkan konsekuensi yang positif, meliputi: Meningkatkan pemahaman terhadap aspek-aspek perilaku konsumen dalam mengambil keputusan pembelian, memperkaya orientasi konsumsi tehadap hal-hal yang bersifat simbolis lebih dari fungsi-fungsi produk, meningkatkan kepercayaan konsumen terhadap produk, meningkatkan keunggulan bersaing berkelanjutan, mengingat inovasi teknologi sangat mudah untuk ditiru oleh pesaing. Hubungan Kualitas Produk terhadap Keputusan Pembelian

Ketika konsumen akan mengambil suatu keputusan pembelian, variabel kualitas produk merupakan pertimbangan paling utama, karena kualitas produk adalah tujuan utama bagi konsumen untuk memenuhi kebutuhannya. Jika konsumen merasa cocok dengan suatu produk dan produk tersebut dapat memenuhi kebutuhannya, maka konsumen akan mengambil keputusan untuk membeli produk tersebut terus menerus (Nabhan dan Kresnaini,2009;429).

\section{Hubungan Harga terhadap Keputusan Pembelian}

Swastha (dikutip oleh Pirendra, 2017;56), mengemukakan jumlah uang yang dibutuhkan untuk mendapatkan sejumlah kombinasi dan barang serta pelayananya. Harga suatu barang menunjukkan nilai dimata konsumen bila bersedia membayar, konsumen menilai bahwa manfaat yang ditimbulkan oleh produk yang ditawarkan telah sesuai dengan uang yang dikeluarkan, hanya saja, biasanya konsumen sering membanding-bandingkan harga dari produk yang memiliki harga murah pada tingkat pelayanan dan produk yang sama.

\section{Hubungan Kualitas Pelayanan terhadap Keputusan Pembelian}

Kualitas layanan merupakan tolak ukur dalam menentukan keputusan pembelian atau tidaknya seorang pengguna jasa, karena melalui kualitas layanan akan dapat menilai kinerja dan merasakan puas atau tidaknya mereka dengan layanan yang diberikan oleh penyedia jasa. kualitas layanan merupakan penilaian menyeluruh atas keunggulan suatu layanan. Bila penilaian yang dihasilkan merupakan penilaian yang positif, maka kualitas layanan ini akan berdampak pada terjadinya keputusan pembelian (Nasution 2012;50).

\section{Hipotesis}

Berdasarkan perumusan masalah maka hipotesis penelitian dapat diuraikan sebagai berikut :

1. Terdapat pengaruh brand image terhadap keputusan pembelian produk semen di PT. Semen Indonesia Logistik Cabang Gulomantung Gresik.

2. Terdapat pengaruh kualitas produk terhadap keputusan pembelian produk semen di PT. Semen Indonesia Logistik Cabang Gulomantung Gresik.

3. Terdapat pengaruh harga terhadap keputusan pembelian produk semen di PT. Semen Indonesia Logistik Cabang Gulomantung Gresik.

4. Terdapat pengaruh kualitas layanan terhadap keputusan pembelian produk semen di PT. Semen Indonesia Logistik Cabang Gulomantung Gresik.

\section{METODOLOGI PENELITIAN}

Jenis penelitian yang digunakan adalah penelitian kuantitatif dengan jenis penelitian ini adalah asosiatif.

\section{Populasi dan Teknik Sampling}

Populasi dalam suatu penelitian sangat diperlukan karena merupakan sasaran pokok objek penelitian. Populasi adalah wilayah generalisasi yang terdiri atas objek/subyek yang mempunyai kualitas dan karakteristik tertentu yang ditetapkan oleh peneliti untuk dipelajari dan kemudian ditarik kesimpulannya (Sugiyono, 2010;115). Berkaitan dengan hal ini maka yang menjadi populasi dalam penelitian ini adalah PT. Semen Indonesia Logistik Cabang Gulomantung Gresik.

Teknik pengambilan sample yang digunakan dalam penelitian ini adalah mengunakan metode nonprobability sampling. Penentuan sampel dalam penelitian ini jumlah populasi tidak diketahui, maka untuk 
memudahkan penentuan jumlah sampel yang diambil ditentukan dengan rumus Riduwan (2012:66) :

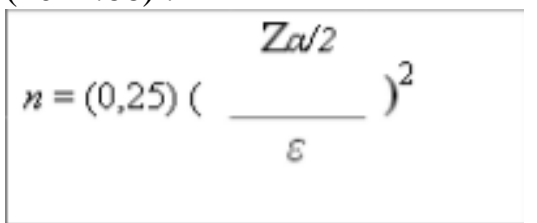

Dimana :

$n=$ jumlah sampel

$\mathrm{Z} \alpha / 2$ = nilai yang didapat dari

tabel normal atas tingkat

keyakinan

$\varepsilon=$ kesalahan penarikan sampel

Tingkat keyakinan dalam penelitian ini ditentukan sebesar $95 \%$ maka nilai $\mathrm{Z} \alpha / 2$ adalah 1.96. tingkat keslahan penarikan sampel ditentukan 5\% maka dari perhitungan tersebut dapat diperoleh sampel yang dibutuhkan yaitu : $2=153,6$

Jadi berdasarkan rumus diatas sampel yang diambil sebanyak 153,6 mahasiswa. Untuk memudahkan perhitungan maka dibulatkan menjadi 154 konsumen atau pelanggan yang datang dan membeli produk semen di PT. Semen Indonesia Logistik Cabang Gulomantung Gresik.

\section{Teknik Pengumpulan Data}

Teknik pengumpulan data dalam penelitian ini menggunakan kuesioner. Menurut sugiyono $(2012 ; 142)$ kuesioner merupakan teknik pengumpuloan data yang dilakukan dengan cara memberikan seperangkat pertanyaan atau pertanyaan tertulis kepada reponden untuk dijawab. Kuesioner digunakan untuk memperoleh data responden mengenai Brand Image, Kualitas Produk, Harga dan Kualitas Layanan terhadap Keputusan Pembelian. Penelitian ini, digunakan daftar pertanyaan bersifat tertutup, dimana alternatif jawaban telah disediakan pada konsumen atau pelanggan dari PT. Semen Indonesia Logistik Cabang Gulomantung Gresik. Agar penelitian lebih efisien mendapatkan data dari responden maka peneliti menggunakan metode kuesioner. Kuesioner tersebut disusun dengan menggunakan lima alternatif jawaban, yaitu SS (sangat setuju), S (setuju), N (netral), TS (tidak setuju), STS (sangat tidak setuju).

\section{HASIL DAN PEMBAHASAN}

\section{Gambaran Umum Perusahaan}

Berangkat dari sebuah Yayasan Sejahtera Semen Gresik. yang didirikan guna mendukung induk perusahaan untuk memperlancar pengangkutan dan distribusi semen ke seluruh pelosok daerah pemasaran PT Semen Gresik (Persero) Tbk. Pada Tahun 1969 merupakan pijakan sukses pertama dengan adanya keberhasilan yang dicapai oleh Yayasan Sejahtera dalam mengelola manajemen dan mengembangkan

\section{Analisis Data}

\section{Uji Instrumen}

Uji instrumen dilakukan untuk mengetahui apakah instrumen yang disusun merupakan hasil yang baik, karena baik buruknya instrumen akan berpengaruh pada benar tidaknya data dan menentukan kualitas hasil penelitian. Berikut adalah hasil uji validitas dan reliabilitas:

\section{Uji Validitas}

\section{Tabel 1. Rekapitulasi Hasil Uji Validitas Instrumen Penelitian}

\begin{tabular}{|l|l|l|l|l|}
\hline No & Item & r tabel & $\begin{array}{l}\text { r } \\
\text { hitung }\end{array}$ & $\begin{array}{l}\text { Keteran } \\
\text { gan }\end{array}$ \\
\hline $\mathbf{1}$ & \multicolumn{5}{|c|}{ X1 } \\
\hline $\mathbf{2}$ & X1.1 & 0,1873 & 0,733 & Valid \\
\hline $\mathbf{3}$ & X1.2 & 0,1873 & 0.812 & Valid \\
\hline $\mathbf{4}$ & X1.3 & 0,1873 & 0,868 & Valid \\
\hline $\mathbf{5}$ & X1.4 & 0,1873 & 0,874 & Valid \\
\hline $\mathbf{6}$ & X2 \\
\hline $\mathbf{7}$ & X2.1 & 0,1873 & 0,857 & Valid \\
\hline $\mathbf{8}$ & X2.2 & 0,1873 & 0,749 & Valid \\
\hline $\mathbf{9}$ & X2.3 & 0,1873 & 0,694 & Valid \\
\hline $\mathbf{1 0}$ & X2.4 & 0,1873 & 0,847 & Valid \\
\hline $\mathbf{1 1}$ & X2.5 & 0,1873 & 0,334 & Valid \\
\hline $\mathbf{1 2}$ & X2.6 & 0,1873 & 0,230 & Valid \\
\hline $\mathbf{1 3}$ & X2.7 & 0,1873 & 0,214 & Valid \\
\hline $\mathbf{1 4}$ & \multicolumn{5}{|c|}{ X3 } \\
\hline $\mathbf{1 5}$ & X3.1 & 0,1873 & 0,893 & Valid \\
\hline $\mathbf{1 6}$ & X3.2 & 0,1873 & 0,759 & Valid \\
\hline $\mathbf{1 7}$ & X3.3 & 0,1873 & 0,721 & Valid \\
\hline $\mathbf{1 8}$ & X3.4 & 0,1873 & 0,885 & Valid \\
\hline $\mathbf{1 9}$ & X4 \\
\hline $\mathbf{2 0}$ & X4.1 & 0,1873 & 0,876 & Valid \\
\hline $\mathbf{2 1}$ & X4.2 & 0,1873 & 0,834 & Valid \\
\hline
\end{tabular}

\section{Sumber : Lampiran 4, 2018}

Berdasarkan tabel diatas menunjukkan bahwa hasil validitas instrumen penelitian ini mempunyai nilai $r$ hitung positif dan lebih besar dari $\mathrm{r}$ tabel dimana tabel $\mathrm{r}$ untuk $\mathrm{df}=\mathrm{n}-2=154$ $-2=152$ tingkat signifikan 5\% adalah 0,1873 dengan demikian maka menunjukkan $r$ hitung $>r$ tabel. Jadi seluruh butir pertanyaan dari seluruh variabel terbukti dapat disimpulkan bahwa 
instrumen penelitian ini valid serta dapat digunakan untuk penelitian.

\section{Uji Reliabilitas}

Reliabilitas dikatakan reliabel apabila memiliki nilai Cronbach Alpha > 0,70 (Nunnally dalam Ghozali, 2013:48).

\section{Rekapitulasi Hasil Uji Reliabilitas}

\begin{tabular}{|l|l|l|l|}
\hline Item & $\begin{array}{l}\text { Cronbach' } \\
\text { s Alpha }\end{array}$ & Alpha & Keterangan \\
\hline $\begin{array}{l}\text { Brand } \\
\text { Image (X1) }\end{array}$ & 0,833 & 0,70 & Reliabel \\
\hline $\begin{array}{l}\text { Kualitas } \\
\text { Produk } \\
\text { (X2) }\end{array}$ & 0,822 & 0,70 & Reliabel \\
\hline Harga (X3) & 0,772 & 0,70 & Reliabel \\
\hline $\begin{array}{l}\text { Kualitas } \\
\text { Layanan } \\
\text { (X4) }\end{array}$ & 0,820 & 0,70 & Reliabel \\
\hline $\begin{array}{l}\text { Keputusan } \\
\text { Pembelian } \\
\text { (Y) }\end{array}$ & 0,811 & 0,70 & Reliabel \\
\hline
\end{tabular}

Sumber: data diolah, 2018

Berdasarkan tabel di atas menunjukkan bahwa masing-masing variabel memiliki nilai Cronbach Alpha > 0,70. Dengan demikian dapat disimpulkan bahwa alat ukur yang digunakan dalam penelitian ini adalah reliabel dan konsistensi indikator bisa digunakan pada waktu yang berbeda.

\section{Uji Asumsi Klasik}

\section{Uji Normalitas}

Data residual berdistribusi normal apabila nilai signifikannya diatas 0,05 . Dan data residual dikatakan tidak normal apabila nilai signifikannya dibawah 0,05 . Berikut adalah hasil pengujian Kolmogorov-Smirnov $(K-S)$ :

\section{One-Sample Kolmogorov-Smirnov Test}

\begin{tabular}{|l|l|l|}
\hline \multicolumn{3}{|l|}{ Unstandardized Residual } \\
\hline $\mathrm{N}$ & \multicolumn{1}{|l|}{154} \\
\hline $\begin{array}{l}\text { Normal } \\
\text { Parameters(a } \\
\text { b) }\end{array}$ & Mean & .0000000 \\
\hline Std. Deviation & 2.16477160 \\
\hline $\begin{array}{l}\text { Most } \\
\text { Extreme } \\
\text { Differences }\end{array}$ & Absolute & .103 \\
\hline Positive & .053 \\
\hline Negative & -.103 \\
\hline
\end{tabular}

\begin{tabular}{|l|l|}
\hline $\begin{array}{l}\text { Kolmogorov- } \\
\text { Smirnov Z }\end{array}$ & 1.281 \\
\hline $\begin{array}{l}\text { Asymp. Sig. (2- } \\
\text { tailed) }\end{array}$ & .075 \\
\hline
\end{tabular}

Pada table diatas menunjukkan bahwa nilai dari Asymp. Sig. (2-tailed) untuk sebesar 0,075 dan melebihi tingkat signifikan yang sudah ditentukan yaitu 0,05 sehingga data dikatakan berdistribusi normal.

\section{Uji Heteroskedastisitas}

Uji heteroskedastisitas pada penelitian ini menggunakan uji glejser. Data dikatakan bebas dari masalah heteroskedastisitas apabila memiliki nilai signifikan yang lebih dari 0,05. Hasil uji glejser dapat dilihat pada tabel berikut ini:

\section{Hasil Uji Glejser}

\begin{tabular}{|l|l|l|}
\hline Bebas & Sig & Keterangan \\
\hline $\begin{array}{l}\text { Brand } \\
\text { Image (X1) }\end{array}$ & 0,792 & $\begin{array}{l}\text { Tidak } \\
\text { Terjadi } \\
\text { Heteroskeda } \\
\text { stisitas }\end{array}$ \\
\hline $\begin{array}{l}\text { Kualitas } \\
\text { Produk (X2) }\end{array}$ & 0,340 & $\begin{array}{l}\text { Tidak } \\
\text { Terjadi } \\
\text { Heteroskeda } \\
\text { stisitas }\end{array}$ \\
\hline Harga (X3) & 0,749 & $\begin{array}{l}\text { Tidak } \\
\text { Terjadi } \\
\text { Heteroskeda } \\
\text { stisitas }\end{array}$ \\
\hline $\begin{array}{l}\text { Kualitas } \\
\text { Layanan } \\
\text { (X4) }\end{array}$ & 0,725 & $\begin{array}{l}\text { Tidak } \\
\text { Terjadi } \\
\text { Heteroskeda } \\
\text { stisitas }\end{array}$ \\
\hline
\end{tabular}

Sumber: data diolah, 2018

Dari tabel diatas didapatkan hasil untuk setiap variabel memiliki nilai signifikan yang lebih dari 0,05 sehingga seluruh variabel pada penelitian ini dikatakan tidak terjadi masalah heteroskedastisitas.

\section{Uji Multikolinieritas}

Uji Multikolonieritas dalam penelitian ini dengan menggunakan dasar keputusan pembelian jika nilai variance inflation factor (VIF) tidak lebih dari 10 dan nilai tolerance (TOL) kurang dari 0,1 maka model dapat dikatakan terbebas dari multikolonieritas (Ghozali, 2013:106). Hasil dari pengelolaan data setiap variabel diperoleh nilai VIF yang tidak lebih dari 10 dan nilai tolerance value kurang dari 0,1 , maka dapat disimpulkan 
bahwa model regresi tidak memiliki masalah multikolonieritas.

\section{Hasil Uji Multikolinieritas}

\begin{tabular}{|l|l|l|}
\hline $\begin{array}{l}\text { Variabel } \\
\text { Bebas }\end{array}$ & Sig & Keterangan \\
\hline $\begin{array}{l}\text { Brand } \\
\text { Image (X1) }\end{array}$ & 0,792 & $\begin{array}{l}\text { Tidak } \\
\text { Terjadi } \\
\text { Heteroskeda } \\
\text { stisitas }\end{array}$ \\
\hline $\begin{array}{l}\text { Kualitas } \\
\text { Produk (X2) }\end{array}$ & 0,340 & $\begin{array}{l}\text { Tidak } \\
\text { Terjadi } \\
\text { Heteroskeda } \\
\text { stisitas }\end{array}$ \\
\hline Harga (X3) & 0,749 & $\begin{array}{l}\text { Tidak } \\
\text { Terjadi } \\
\text { Heteroskeda } \\
\text { stisitas }\end{array}$ \\
\hline $\begin{array}{l}\text { Kualitas } \\
\text { Layanan } \\
\text { (X4) }\end{array}$ & 0,725 & $\begin{array}{l}\text { Tidak } \\
\text { Terjadi } \\
\text { Heteroskeda } \\
\text { stisitas }\end{array}$ \\
\hline
\end{tabular}

Sumber: data diolah, 2018

\section{Analisis Regresi Linier Berganda}

Analisis regresi linier berganda dimaksud untuk menganalisis pengaruh dari variabel Brand Image (), Kualitas Produk (), Harga () dan Kualitas Layanan () terhadap Keputusan Pembelian (Y) di PT. Semen Indonesia Logistik Cabang Gulomantung Gresik. Pengujian dilakukan dengan bantuan SPSS v.25 didapatkan hasil pada tabel berikut:

\section{Hasil Uji Regresi Linier Berganda}

\begin{tabular}{|l|l|l|l|l|}
\hline \multicolumn{5}{|c|}{ Coefficients(a) } \\
\hline Model & \multicolumn{2}{|l|}{$\begin{array}{l}\text { Unstandardized } \\
\text { Coefficients }\end{array}$} & $\mathrm{t}$ & Sig. \\
\hline $\mathrm{B}$ & \multicolumn{2}{|l|}{ Std. Error } & Tolerance & VIF \\
\hline (Constant) & 3.987 & 1.401 & 2.846 & .005 \\
\hline $\begin{array}{l}\text { Brand } \\
\text { Image }\end{array}$ & .218 & .077 & 2.823 & .005 \\
\hline $\begin{array}{l}\text { Kualitas } \\
\text { Produk }\end{array}$ & .374 & .188 & 1.991 & .048 \\
\hline Harga & .566 & .238 & 2.379 & .019 \\
\hline $\begin{array}{l}\text { Kualitas } \\
\text { Layanan }\end{array}$ & -.396 & .148 & -2.664 & .009 \\
\hline
\end{tabular}

Sumber: data diolah, 2018

Persamaan regresi dalam penelitian ini adalah sebagai berikut:

$\mathrm{Y}=\mathrm{a} 1+\mathrm{b} 1 \mathrm{X} 1+\mathrm{b} 2 \mathrm{X} 2+\mathrm{b} 3 \mathrm{X} 3+\mathrm{b} 4 \mathrm{X} 4+\mathrm{e}$

$\mathrm{Y}=3,987+0,218 \mathrm{X} 1+0,374 \mathrm{X} 2+0,566 \mathrm{X} 3-$ $0,396 \mathrm{X} 4+\mathrm{e}$

Persamaan regresi pada tabel diatas dapat dijelaskan sebagai berikut:
1. Konstanta sebesar 3,987, artinya jika Brand Image (X1), Kualitas Produk (X2), Harga (X3) dan

Kualitas Layanan (X4) nilainya adalah 0, maka Keputusan Pembelian (Y) nilainya adalah 3,987. Maka jika Brand Image (X1), Kualitas Produk (X2), Harga (X3) dan Kualitas Layanan (X4) nilainya adalah 0, maka Keputusan Pembelian (Y) meningkat sebesar $3,987$.

2. Nilai koefisien regresi dari vaiabel Brand Image (X1) adalah sebesar 0,218 yang artinya apabila variabel Brand Image (X1) berubah, maka Keputusan Pembelian (Y) akan meningkat sebesar 0,218 dengan asumsi Kualitas Produk (X2), Harga (X3) dan Kualitas Layanan (X4) nilainya tetap. Koefisien dengan nilai positif yang artinya terdapat hubungan atau pengaruh positif antara Brand Image (X1) dengan Keputusan Pembelian (Y).

3. Nilai koefisien regresi dari vaiabel Kualitas Produk (X2) adalah sebesar 0,374 yang artinya apabila variabel Kualitas Produk (X2) berubah, maka Keputusan Pembelian (Y) akan meningkat sebesar 0,374 dengan asumsi Brand Image (X1), Harga (X3) dan Kualitas Layanan (X4) nilainya tetap. Koefisien dengan nilai positif yang artinya terdapat hubungan atau pengaruh positif antara Kualitas Produk (X2) dengan Keputusan Pembelian (Y).

4. Nilai koefisien regresi dari vaiabel Harga (X3) adalah sebesar 0,566 yang artinya apabila variabel Harga (X3) berubah, maka Keputusan Pembelian (Y) akan meningkat sebesar 0,566 dengan asumsi Brand Image (X1), Kualitas Produk (X2) dan Kualitas Layanan (X4) nilainya tetap. Koefisien dengan nilai positif yang artinya terdapat hubungan atau pengaruh positif antara Kualitas Harga (X3) dengan Keputusan Pembelian (Y).

5. Nilai koefisien regresi dari vaiabel Kualitas Layanan (X4) adalah sebesar -0,396 yang artinya apabila variabel Kualitas Layanan (X4) berubah, maka Keputusan Pembelian (Y) akan menurun sebesar 0,396 dengan asumsi Brand Image (X1), Kualitas Produk (X2) dan Harga (X3) nilainya tetap. Koefisien dengan nilai negatif yang artinya terdapat hubungan atau pengaruh negatif antara Kualitas Layanan (X4) dengan Keputusan Pembelian (Y). 
Koefisien Determinasi (R2)

Koefisien korelasi (R) digunakan untuk mengetahui hubungan antar variabel bebas $(\mathrm{X})$ terhadap variabel terikat (Y) secara bersama. Koefisien determinasi () pada intinya mengukur seberapa jauh kemampuan model dalam menerangkan variasi variabel independen. Koefisien determinasi () dapat dilihat pada tabel berikut :

\section{Hasil Analisis Koefisien Determinasi (R2)}

Model Summary(b)

\begin{tabular}{|l|l|l|l|}
\hline Model & $\mathrm{R}$ & $\begin{array}{l}R \\
\text { Square }\end{array}$ & $\begin{array}{l}\text { Adjuste } \\
\text { d R } \\
\text { Square }\end{array}$ \\
\hline 1 & $.631(\mathrm{a})$ & .398 & .382 \\
\hline
\end{tabular}

a. Predictors: (Constant), Kualitas Layanan,

Brand Image, Kualitas Produk, Harga

b Dependent Variable: Keputusan Pembelian Sumber: data diolah, 2018

Nilai Adjusted R Square menunjukkan bahwa nilai Keputusan Pembelian (Y) sebesar 38,2\% disebabkan oleh variabel Brand Image (X1), Kualitas Produk (X2), Harga (X3) dan Kualitas Layanan (X4) sedangkan sisanya sebesar 61,8\% disebabkan oleh faktor lain yang tidak ada dalam penelitian ini.

\section{Uji Hipotesis}

Hasil pengujian uji hipotesis dapat ditunjukkan pada tabel sebagai berikut:

\section{Coefficients(a)}

\section{Hasil Analisis Uji t}

\begin{tabular}{|l|l|l|l|l|}
\hline \multicolumn{2}{|l|}{$\begin{array}{l}\text { Unstandardized } \\
\text { Coefficients }\end{array}$} & $\mathrm{t}$ & Sig. \\
\hline Model & $\mathrm{B}$ & $\begin{array}{l}\text { Std. } \\
\text { Error }\end{array}$ & Tolerance & VIF \\
\hline (Constant) & 3.987 & 1.401 & 2.846 & .005 \\
\hline $\begin{array}{l}\text { Brand } \\
\text { Image }\end{array}$ & .218 & .077 & 2.823 & .005 \\
\hline $\begin{array}{l}\text { Kualitas } \\
\text { Produk }\end{array}$ & .374 & .188 & 1.991 & .048 \\
\hline Harga & .566 & .238 & 2.379 & .019 \\
\hline $\begin{array}{l}\text { Kualitas } \\
\text { Layanan }\end{array}$ & -.396 & .148 & -2.664 & .009 \\
\hline \multicolumn{5}{|l|}{ Sumber: data diolah, 2018 } \\
\hline
\end{tabular}

Berdasarkan pada tabel diatas dapat dijelaskan bahwa:

1. Variabel Brand Image (X1) memiliki nilai signifikansi sebesar 0,005 $<0,05$, maka Ho ditolak dan Ha diterima artinya Brand Image
(X1) berpengaruh signifikan terhadap Keputusan Pembelian (Y).

2. Variabel Kualitas Produk (X2) memiliki nilai signifikansi sebesar 0,048 $<0,05$, maka Ho ditolak dan $\mathrm{Ha}$ diterima artinya Kualitas Produk (X2) berpengaruh signifikan terhadap Keputusan Pembelian (Y).

3. Variabel Harga (X3) memiliki nilai signifikansi sebesar 0,019<0,05, maka Ho ditolak dan Ha diterima artinya Harga (X3)

berpengaruh signifikan terhadap Keputusan Pembelian (Y).

4. Variabel Kualitas Layanan (X4) memiliki nilai signifikansi sebesar 0,009 $<0,05$, maka Ho ditolak dan Ha diterima artinya Kualitas Layanan (X4) berpengaruh signifikan terhadap Keputusan Pembelian (Y).

\section{PEMBAHASAN}

\section{Pengaruh Brand Image terhadap Keputusan Pembelian}

Hasil penelitian ini menunjukkan bahwa variabel Brand Image (X1) memiliki nilai signifikansi sebesar $0,005<0,05$, terbukti bahwa variabel Brand Image (X1) berpengaruh signifikan terhadap Keputusan Pembelian (Y). Hal Ini sejalan pendapat Wicaksono $(2011 ; 153)$, mengemukakan pentingnya pengembangan Brand Image dalam keputusan pembelian. Brand image yang dikelola dengan baik akan menghasilkan konsekuensi yang positif, meliputi: Meningkatkan pemahaman terhadap aspek-aspek perilaku konsumen dalam mengambil keputusan pembelian, memperkaya orientasi konsumsi tehadap hal-hal yang bersifat simbolis lebih dari fungsi-fungsi produk, meningkatkan kepercayaan konsumen terhadap produk, meningkatkan keunggulan bersaing berkelanjutan, mengingat inovasi teknologi sangat mudah untuk ditiru oleh pesaing.

\section{Pengaruh Kualitas Produk terhadap Keputusan Pembelian}

Hasil penelitian ini menunjukkan bahwa variabel Kualitas Produk (X2) memiliki nilai signifikansi sebesar $0,048<0,05$, terbukti bahwa variabel Kualitas Produk (X2) berpengaruh signifikan terhadap Keputusan Pembelian (Y). Salah satu penyumbang terbesar mengenai pengaruh kualitas produk ini adalah pada dimensi material semen Gresik yang cepat mengeras dan tahan lama. Menurut Lupiyoadi (2008:137) menyatakan bahwa semakin baik kualitas yang dimiliki akan meningkatkan 
pembelian. Tuntutan terhadap kualitas suatu produk sudah menjadi suatu keharusan yang harus dipenuhi oleh perusahaan, kalau tidak menginginkan konsumen yang telah dimilikinya beralih kepada produk-produk pesaing lainnya. Konsumen menginginkan produk yang dibelinya sesuai dengan keinginannya atau produk tersebut berkualitas. Hal ini didukung oleh penelitian yang dilakukan oleh Lina (2017), Cindy (2017), Joshua \& Padmalia (2016), Habibah \& Sumiati (2016), Riyono \& Budiharja (2016) serta Murwatiningsih \& Apriliani (2013).

\section{Pengaruh Harga terhadap Keputusan Pembelian}

Hasil penelitian ini menunjukkan bahwa variabel Harga (X3) memiliki pengaruh yang signifikan terhadap Keputusan Pembelian (Y) hal ini dibuktikan bahwa variabel Harga (X4) memiliki nilai signifikansi sebesar 0,019<0,05. Dari kajian dilapangan, sebagian responden menyatakan setuju bahwa Meskipun harga pada produk semen Gresik lebih mahal dibandingkan dengan harga produk semen lainnya, namun konsumen memilih semen gresik karena memiliki kualitas yang baik dibandingkan dengan semen lainnya. Berdasarkan kajian dilapangan, sebagian responden menyatakan setuju bahwa semen Gresik memiliki harga yang sesuai dengan kualitas yang diberikan oleh PT. Semen Indonesia Harga sering dijadikan faktor kualitas oleh konsumen.

Konsumen sering memilih harga yang relatif lebih tinggi diantara beberapa jenis semen, karena mereka melihat adanya perbedaan kualitas didalamnya. Apabila harga lebih tinggi konsumen cenderung beranggapan kualitasnya juga lebih baik. Konsumen juga sering menggunakan harga sebagai kriteria dalam menentukan nilainya. Harga yang dipilih akan berpengaruh langsung terhadap tingkat permintaan dan menentukan tingkat aktivitas pembelian serta harga juga akan mampu mendorong penjualan dan pangsa pasar (Tjiptono, 2015:291). Hasil penelitian ini didukung oleh penelitian yang dilakukan Joshua dan Padmalia (2016), Habibah dan Sumiati (2016), Fitrianingrum dan Wahyono (2013), Samosir dan Prayoga (2015) dan Lufiana (2016).

\section{Pengaruh Kualitas Layanan}

Hasil penelitian ini menunjukkan bahwa variabel Kualitas Layanan (X4) memiliki pengaruh negatif dan signifikan terhadap
Keputusan Pembelian ( $\mathrm{Y}$ ) hal ini dibuktikan bahwa variabel Kualitas Layanan (X4) memiliki nilai signifikansi sebesar $0,009<0,05$. Konsumen yang ingin membeli suatu produk, pelayanan yang diberikan saat memilih sampai terjadinya transaksi pembelian sangatlah berpengaruh terhadap keputusan pembelian yang dilakukan oleh konsumen.

Pelayanan yang kurang baik akan menimbulkan rasa tidak puas yang dirasakan oleh konsumen dan selanjutnya akan mempengaruhi tingkat penjualan pada waktu selanjutnya. Hal ini sejalan dengan pendapat (Nasution 2012;50) Kualitas layanan merupakan tolak ukur dalam menentukan keputusan pembelian atau tidaknya seorang pengguna jasa, karena melalui kualitas layanan akan dapat menilai kinerja dan merasakan puas atau tidaknya mereka dengan layanan yang diberikan oleh penyedia jasa. kualitas layanan merupakan penilaian menyeluruh atas keunggulan suatu layanan. Bila penilaian yang dihasilkan merupakan penilaian yang positif, maka kualitas layanan ini akan berdampak pada terjadinya keputusan pembelian.

\section{KESIMPULAN DAN SARAN}

\section{Kesimpulan}

Berdasarkan uraian-uraian yang telah diungkapkan pada pembahasan, maka dapat diambil beberapa kesimpulan antara lain:

1. Brand Image berpengaruh signifikan terhadap keputusan pembelian Semen di PT. Semen Indonesia Logistik Cabang Gulomantung Gresik.

2. Kualitas Produk berpengaruh signifikan terhadap keputusan Semen di PT. Semen Indonesia Logistik Cabang Gulomantung Gresik.

3. Harga berpengaruh signifikan terhadap keputusan Semen di PT. Semen Indonesia Logistik Cabang Gulomantung Gresik.

4. Kualitas Layanan berpengaruh negatif dan signifikan terhadap keputusan Semen di PT. Semen Indonesia Logistik Cabang Gulomantung Gresik.

\section{Saran}

Berdasarkan penelitian yang sudah dilakukan, maka peneliti dapat memberikan rekomendasi sebagai berikut:

Bagi Perusahaan

1) Melihat hasil penelitian ini harga memiliki pengaruh yang paling besar terhadap 
keputusan pembelian Semen di PT. Semen Indonesia Logistik Cabang Gulomantung Gresik, oleh karena itu perusahaan harus menjaga kestlabilan harga semen agar dapat menarik konsumen.

2) PT. Semen Indonesia Gresik diharapkan dapat menjaga dan meningkatkan kualitas produk dan kualitas layanan semen agar dapat menjadikan kepercayaan bagi pelanggan dan menarik konsumen.

3) Variabel brand image memiliki pengaruh yang paling rendah dalam penelitian ini, sehingga perusahaan harus lebih berfikir untuk memberikan penambahan brand yang menarik atau unik pada produk semen agar dapat menarik konsumen.

Bagi Penelitian Selanjutnya

Bagi peneliti selanjutnya hasil penelitian ini dapat digunakan sebagai referensi bagi peneliti selanjutnya dengan mengkaji kembali kualitas layanan dengan keputusan pembelian dalam kontek pembelian business to consumer dan business to business.

\section{DAFTAR PUSTAKA}

Amrullah, Pamasang S. Siburian, Saida Zainuros salamia Za, 2016, Pengaruh Kualitas Produk Dan Kualitas Layanan Terhadap Keputusan Pembelian Sepeda Motor Honda, Jurnal Ekonomi Dan Manajemen, Volume 13, (2), 2016, Hal 99-118

Buchari Alma. 2011. Manajemen Pemasaran Dan Pemasaran Jasa. Bandung : Penerbit Alfabeta.

Buchari Alma. 2016, Manajemen Pemasaran \& Pemasaran Jasa. Cetakan keenam, Bandung:Alfabeta.

Fadila dan Ridho. 2013. Perilaku Konsumen. Palembang. Penerbit Citra Books Indonesia.

Ferrinadewi, Erna. 2008, Merek dan Psikologi Konsumen, Implikasi pada Strategi Pemasaran. Yogyakarta: Graha Ilmu.

Firzsa Nabila Pravianda, 2017, Pengaruh Harga Dan Reputasi Perusahaan Terhadap Keputusan Pembelian Produk Niion Indonesia (Studi Kasus Pada Konsumen Di Kota Bandung), Repository | Thesis | Bachelor Of Communication - S1 | Faculty Of Computer Science | Dinus University | 2017.
Fuad, M, dkk. 2009. Pengantar Bisnis. Cetakan Kelima. Jakarta : PT Gramedia Pustaka Utama.

Garvin, D.A. 2012. Kualitas Produk : Alat Strategi Yang Penting. Jakarta : Free Press. Edisi III.

Ghozali, Imam, 2013, Aplikasi Analis Multivariate Dengan Program Ibm Spss 21, Edisi 2, Universitas Diponegoro, Semarang.

Kanisius Waro Wanda, 2015, pengaruh Harga Dan Pelayanan Terhadap Keputusan Pembelian Di Mini Market Lulu Mart Samarinda, eJournal Ilmu Administrasi Bisnis, 2015, 3 (4): 757-768.

Keller, Kevin Lane, 2013, Strategy Brand Management (Building, Measuring and Managing Brand Equity), Fourth Edition, United State: Pearson.

Kotler Philip, Amstrong Gary. 2013. Prinsipprinsip Pemasaran, Edisi ke-12. Penerbit Erlangga.

Kotler, Philip And Gary Armstrong. 2012. Prinsip-prinsip pemasaran. Edisi 13. Jilid 1. Jakarta: Erlangga.

Kotler, Philip and Gray Armstrong. 2008. Prinsip-prinsip Pemasaran. Edisi 12. Jilid 1. Jakarta: Erlangga.

Kotler, Philip and Gray Armstrong. 2009. Prinsip-prinsip Pemasaran. Edisi 12. Jilid 2. Jakarta: Erlangga.

Kotler, Philip. 2009. Marketing Jilid 2. Jakarta: Erlangga

Lupiyoadi, Rambat. 2013. Manajemen Pemasaran Jasa. Jakarta: Salemba Empat.

Priansa, Donni Juni. 2017. Perilaku Konsumen dalam Bisnis Kontemporer. Bandung: Alfabeta.

Radji, Djoko Lesmana. 2009, Hubungan Citra Merek, Kepuasan dan Loyalitas Konsumen. Jurnal Bisnis dan Manajemen, Jurnal Fakultas Ekonomi dan Bisnis Universitas Negeri Gorontalo, Vol.10 (1) 17-34.

Riduwan. 2012, Belajar Mudah Penelitian: Untuk Guru-Karyawan dan Peneliti Pemula.CV Alfabeta. Bandung

Schiffman dan Kanuk. 2008. Perilaku konsumen. Edisi 7. Jakarta: Indeks.

Sugiyono, 2010, Metode Penelitian Kuantitatif, Kualitatif, Dan R\&B, Cetakan Ke-15, Alfabeta, Bandung. 
Sugiyono, 2012, Metode Penelitian Kuantitatif, Kualitatif, Dan R\&B, Cetakan Ke-16, Alfabeta, Bandung.

Sugiyono, 2013, Metode Penelitian Kuantitatif, Kualitatif, Dan R\&B, Cetakan Ke-17, Alfabeta, Bandung.

Sugiyono, 2014, Metode Penelitian Kuantitatif, Kualitatif, Dan R\&B, Cetakan Ke-19, Alfabeta, Bandung.

Sugiyono, 2015, Metode Penelitian Kuantitatif, Kualitatif, Dan R\&B, Cetakan Ke-20, Alfabeta, Bandung.

Suparyanto dan Rosad. 2015. Manajemen Pemasaran. Bogor: In Media.

Tjiptono, Fandy, 2008, Strategi Pemasaran, Edisi 3, Andi: Yogyakarta.

Tjiptono, Fandy. 2010, Strategi Pemasaran. Edisi 2. Yogyakarta: Andi Offset.

Tjiptono, Fandy., Chandra Gregorius. 2016, Servies, Quality \& Satisfastion. Edisi 4, Yogyakarta:Andi Offset.

Visser, Gattol, Dan Van Der Helm.2015. Communicating Sustainable Shoes To Mainstream Consumers : The Impact Of Advertisement Design On Buying Intention. Journal of Management Business. 